\title{
Evaluation of efficacy, safety and antioxidant effect of Nigella sativa in patients with psoriasis: A randomized clinical trial
}

\author{
Psöriazisli hastalarda çörek otunun etkinlik, güvenirlik ve antioksidan etkileri: Randomize bir \\ klinik çalışma
}

Ahmed Jawad H. ${ }^{1}$, Ibraheem Azhar Y. ${ }^{2}$, Al-Hamdi Khalil I. ${ }^{3}$

\begin{abstract}
Objective: Various drugs are used for treatment of psoriasis such as retinoids, hydroxyurea, methotrexate, and infliximab with variable benefits, but these drugs are associated with side effects. The aim of this study was to evaluate efficacy, safety of topical and oral doses of Nigella sativa (NS) in psoriatic patients.
\end{abstract}

Methods: sixty patients with mild to moderate plaque and palmoplanter psoriasis were recruited for the study from January 2010 to March 2011. The patients were randomly divided into three groups: Twenty patients (group 1) were treated with $(10 \% \mathrm{w} / \mathrm{w})$ ointment of (NS), group 2 (20 patients) treated with crude powder of (NS), $500 \mathrm{mg}$ capsule t.d.s; group 3 (20 patients) were treated with the combination of ointment and capsule of (NS).PASI score was used for clinical evaluation of effect, and serum malondialdehyde (MDA) as an indicator of oxidative status.

Results: (NS) ointment achieved complete cure of psoriatic lesions, excellent and good response in $65 \%$ of patients, with a relapse rate of $31 \%$ four weeks after cessation of treatment. Oral doses of (NS) produced good response in $50 \%$ of patients, with a relapse rate of $50 \%$ noticed four weeks after treatment cessation. The combination of (NS) ointment and oral doses achieved complete cure of lesions, excellent and good responses in $85 \%$ of patients, with a relapse rate of $18 \%$. (NS) was well tolerated, no side effects were observed.

Conclusion: (NS) has anti psoriatic effect with the best effect obtained with the combination of ointment and the oral dosage form of (NS). J Clin Exp Invest 2014; 5 (2): 186-193

Key words: Nigella sativa, Plague psoriasis, antioxidant, efficacy
ÖZET

Amaç: Psöriazis tedavisinde retinoidler, hidroksiüre, metotreksat ve infliksimab gibi pek çok ilaç farklı etkinlikleriyle kullanılmıştır. Ancak bu ilaçların yan etkileri vardır. Bu çalışmanın amacı, pöriatik hastalarda çörek otunun topikal ve oral dozlarının etkinlik ve güvenirliğini değerlendirmektir.

Yöntemler: Hafif ve orta plaklı ve palmoplantar psöriazisli 60 hasta Ocak 2010 ile Mart 2011 arasında çalışmaya alındı. Hastalar rastgele üç gruba ayrıldı: 20 hasta (Grup 1) \%10'luk çörek otu merhemi ile, Grup 2'deki 20 hasta çörek otunun 500 mg'lık kuru tozunu içeren kapsüller ile günde 3 defa tedavi edildi. Grup 3'teki 20 hasta ise hem çörek otu merhemi, hem de kapsülleri ile tedavi edildi. PASı skoru etkinliğin değerlendirilmesi ve serum malondialdehid düzeyi oksidatif durum belirteci olarak kullanıldı.

Bulgular: Çörek otu merhemi ile psöriyatik lezyonlarda $\% 65$ oranında tam düzelme veya mükemmel ve iyi cevap alındı. Oral çörek otu hastaların \%50'sinde iyi cevap verdi, ancak tedavi kesilmesinden 4 hafta sonra \%50 oranında rölaps gözlendi. Merhem ve oral çörek otu kombinasyonu ile vakaların \%85'inde mükemmel ve iyi cevap alındı ve kombinasyon tedavisi sonrası \%18 rölaps oldu. Çörek otu iyi tolere edildi ve herhangi bir yan etki gözlenmedi.

Sonuçlar: Çörek otu antipsöriatik etkilre sahiptir ve bu etkiler en iyi merhem ve oral formlarının kombine verilmesi ile elde edilir.

Anahtar kelimeler: Çörek otu, psöriazis plakları, antioksidan etki, etkinlik

\footnotetext{
${ }^{1}$ Department of Pharmacology, College of Medicine, University of Basrah, Iraq

2 Department of Pharmacology, College of pharmacy, University of Basrah, Iraq

${ }^{3}$ Department of Dermatology, College of Medicine, University of Basrah, Iraq
}

Correspondence: Jawad H. Ahmed,

Department of Pharmacology, College of Medicine, University of Basrah, Iraq Email: jawadahmed_basmed@yahoo.com

Received: 08.03.2014, Accepted: 24.04.2014

Copyright @ JCEI / Journal of Clinical and Experimental Investigations 2014, All rights reserved 


\section{INTRODUCTION}

Psoriasis is a common distressing, relapsing dermatological disease with no particular curative topical or systemic treatment [1]. It affects $1 \%$ to $3 \%$ of the world's population [2]. Although it is considered a benign disorder, it has a severe impact on the quality of life. Various drug regimens are used with variable benefits such steroids which are effective and rapidly clearing skin lesions but distressing side effects and relapse of the disease is inevitable [3]. Other treatments are either expensive or having even more severe side effects such as hydroxyurea, retinoids, methotrexate, [4] and infliximab [5]. Therefore, investigating safe compounds for the treatment of psoriasis is tempting. Oral zinc as a monotherapy or in combination with methotrexate had been tried in chronic plaque psoriasis with a promising result [6]. Nigella sativa (NS) has been shown in few published studies as an effective agent in the treatment of various dermatological diseases such as eczema or atopic dermatitis $[7,8]$. However, it can be anticipated that (NS) is effective in various skin conditions since it has antibacterial,[9]immune modulation, [10,11] antioxidant, [12] and antihistaminic effects, [13] in addition, to its anti-tumor, cell cycle regulatory activity,[14] and apoptosis induction activity [15]. The present study, therefore, was design to investigate the effectiveness of (NS) in patients with psoriasis.

\section{METHODS}

Eighty six patients with chronic psoriasis consulting the outpatient clinic at the Department of Dermatology and Venereology at teaching hospital during the period from January 2010 to March 2011 were recruited for the study. Initial sample size calculation were based on recruiting this number of patients for the study to achieve $80 \%$ power to detect $25 \%$ difference in PASI score using a formula for one-tailed unpaired t-test [16]. Sample size was recalculated after exclusion of patients. Twenty four patients were excluded from the study; three women were pregnant or planning for pregnancy, ten patients had severe psoriasis in which systemic treatment cannot be stopped, 11 patients were excluded because they were lost during follow up (three patients from group 1, eight patients from group 2 and 3). Sixty patients with mild, moderate plaque and palmoplanter psoriasis had completed the study. The study was an open-label, therapeutic, outpatientbased and included both males and females in the age range (5-70) years. The patients were asked to stop topical or systemic treatments two weeks prior to the study or can be kept on Vaseline ointment as emollient agent if required.

The patients were interviewed, detailed history including age, gender, occupation, residence, duration of the disease, family history, history of previous treatment, seasonal variations and smoking were obtained. The diagnosis was made clinically by the same dermatologist. The study protocol was explained to the patients and written informed consents were obtained from all participants. The study was approved by a local institutional ethical committee. Sequentially numbered container was prepared by the principal investigator and used for randomization and dividing the patients into three groups: patients in group 1 (20 patients) were treated with $(10 \% \mathrm{w} / \mathrm{w})$ ointment of (NS) applied twice daily in the morning and evening for 12 weeks. The ointment was prepared by mixing $10 \mathrm{gm}$ of the fixed oil extract of (NS) (extracted by a soxholet method) with $90 \mathrm{gm}$ white Vaseline in a small container. The container was then heated in a water bath at $40^{\circ} \mathrm{C}$ for 15 min until a liquid homogenized mixture was obtained. Group 2 (20 patients) were treated with a crude powder of (NS) $(500 \mathrm{mg}$ capsule three times daily) for 12 weeks. The powder was obtained by mechanically grinding (NS) seeds for 6 minutes using ordinary grinder, $500 \mathrm{mg}$ of the fine powder then filled in a hard gelatin capsule size (0).

Patients in group 3 (20 patients) were treated with the combination of ointment $(10 \% \mathrm{w} / \mathrm{w})$ and capsules $(500 \mathrm{mg}$ ) of (NS) three times daily for 12 weeks.

Patients were seen every two weeks for 12 weeks. At the end of 12 weeks the response to treatment or appearance of side effects were evaluated. Relapse rate was evaluated 4 weeks after treatment cessation.

\section{Measurement and assessment of response}

\section{1- Clinical assessment (PASI-score)}

PASI (Psoriasis Area and Severity Index) score was selected to evaluate the extent of the disease and to monitor the therapeutic response. PASI score was monitored before, during and after treatment [17] Evaluation of the response was made after 4,8 and 12 weeks of treatment and presented as \% reduction of PASI Score from baseline values.

Patients were considered responders if the reduction in PASI was $50 \%$ or more. Relapse occurred after treatment cessation and reported 
only for patients who achieved $50 \%$ improvement or more, then fell below $50 \%$ from base line PASI score values [18]. Response to treatment was divided arbitrarily into four categories: complete cure when psoriatic lesions completely cleared $(100 \%)$; excellent when the \% reduction in PASI score was between $75-99 \%$; good response when the \% reduction in PASI score was 50-74\%; partial response when the \% reduction in PASI score between 25-49 $\%$.No response when the \% reduction in PASI score $<25 \%$.

\section{2- Photographic viewing}

Photographs were taken every two weeks by a high resolution digital camera (10.1 mega pixel).

\section{3- Patients satisfaction}

Patients satisfaction was evaluated, scored in percentage from 1 to $100 \%$. They were labeled not satisfied if they mentioned a percentage of satisfaction less than $25 \%$, partially satisfied $25-49 \%$, highly satisfied (50-100\%).

\section{4- Indicator of oxidative status: measurement of malondialdehyde level (MDA)}

Oxidative status was evaluated at baseline and at the end of 12 weeks of treatment by measuring MDA levels according to the thiobarbituric acid assay of Beuge and Aust (1978) [19].

\section{Statistical analysis}

The data were entered first to an Excel spreadsheet, examined, and then transferred into a statistical package (SPSS version 15) for analysis. KruskalWallis, a non-parametric test was used for investigating differences between the means of the three groups. Mann-Whitney $U$ test was used for comparison of means between two groups. Chi-square was used where appropriate. $P$ value less than 0.05 was considered significant. The data were presented as mean plus minus standard deviation.

\section{RESULTS}

Sixty patients completed the study; twenty eight $(46.7 \%)$ of them were males with a mean age of $(35.7+11.9)$ years, $32(53.3 \%)$ were females with a mean age of $(35.3+12.9)$ years. Family history of psoriasis was positive in 20 patients (33.3\%). mild to severe itching was reported in $(80 \%)$ of patients. It was mild in $(40 \%)$ of patients, moderate and severe in $(35 \%)$, and $(25 \%)$ respectively.

Twenty two male patients (36.7\%) were smoker. Anxiety, as an aggravating factor, was reported in $40(66.7 \%)$ patients. In $25(41.7 \%)$ patients, the disease increased in severity in summer while 20 $(33.3 \%)$ of them reported increased severity during winter and $15(25 \%)$ patients reported increased severity in spring.

\section{Clinical assessment of the response to the treatments}

The mean baseline value of PASI score in the patients who received ointment of (NS) $(10 \% \mathrm{w} / \mathrm{w})$ twice daily (group1) was 9.0+3.7. The PASI score started to decline as the treatment continued, and at the end of $4,6,8,10$ and 12 weeks of treatment the mean PASI score + SD became 7.2+3.3, 6.6+3, $5.6+2.8,5+2.5$ and $4.3+2$, respectively. These values were significantly different from the baseline value (Table 1).

The mean baseline PASI score in patients (group2) on the crude powder capsule of (NS) (500mg three times daily) was $9.9+3.4$, and significantly declined to $5.4+2.7$ at the end of 12 weeks of treatment (Table 1).
Table 1. Effect of treatments on PASI scores (Mean+SD) at $2,4,6,8,10$ and 12 weeks.

\begin{tabular}{cccc}
\hline Weeks & $\begin{array}{c}\text { Group 1 } \\
\text { Ointment of } \\
\text { Nigella sativa }(\mathrm{n}=20)\end{array}$ & $\begin{array}{c}\text { Group 2 } \\
\text { Capsule of } \\
\text { Nigella sativa }(\mathrm{n}=20)\end{array}$ & $\begin{array}{c}\text { Group 3 } \\
\text { Combination of ointment and } \\
\text { capsules of Nigella sativa }(\mathrm{n}=20)\end{array}$ \\
\hline Baseline & $9.0 \pm 3.7$ & $9.9 \pm 3.4$ & $10.9 \pm 2.7$ \\
2 & $8.2 \pm 3.7$ & $9.2 \pm 3.4$ & $9.9 \pm 2.5^{*}$ \\
4 & $7.2 \pm 3.3^{*}$ & $8.2 \pm 3.5$ & $7.8 \pm 2.2^{*}$ \\
6 & $6.6 \pm 3^{*}$ & $7.5 \pm 3.3$ & $6.0 \pm 2.1^{*}$ \\
8 & $5.6 \pm 2.8^{*}$ & $6.8 \pm 3.1^{*}$ & $5.0 \pm 1.8^{*}$ \\
10 & $5.0 \pm 2.5^{*}$ & $6.3 \pm 3^{*}$ & $4.4 \pm 1.8^{*}$ \\
12 & $4.3 \pm 2.0^{*}$ & $5.4 \pm 2.7^{*}$ & $4.2 \pm 1.7^{*}$ \\
\hline
\end{tabular}

* Significantly different from the corresponding baseline value $(P$-value $<0.05)$. 
The reduction in PASI score in patients on the combination(ointment and capsules) of (NS) was slightly more than the reduction observed in the ointment treated group. The mean baseline PASI score was $10.9+2.7$, and declined to $9.9+2.5,7.8+2.2$, $6+2.1,5+1.8,4.4+1.8$ and $4.2+1.7$ at the end of 2 , $4,6,8,10$ and 12 weeks of treatment respectively, these values were significantly different from the baseline value $\mathrm{P}<0.05$ (Table 1).

The magnitude of change in PASI score was calculated as \% reduction from baseline PASI score values and presented in (Table 2).

The mean value of \% reduction from baseline PASI score in patients on the ointment of (NS) (group 1) at week 4 of treatment was $21.7+11.2 \%$. This became $39+12 \%$ at 8 weeks and $52.6+7.1$ at 12 weeks of treatment. Significant differences were achieved at the 8 and 12 weeks compared to the 4 weeks values $(P<0.05)$.

In patients treated with the crude powder capsule of (NS) (group 2) the mean \% reduction from baseline PASI score at week 4 of treatment was $19.6+7.8 \%$ which became, as the treatment continued, $34.2+11.4 \%$ at the end of 8 weeks and $47.5+$ $11.6 \%$ at the end of 12 weeks of treatment. These values were significantly different from the 4 weeks values (Table 2 ).

Better response was noticed in patients on the combination of ointment and capsules (group 3 ), the mean $\%$ reduction from baseline values of PASI score at week 4 of treatment was $29+8.7 \%$, and this became $54.7+7.2 \%$ and $62.1+13.6 \%$ at 8 and 12 weeks respectively. The difference from the 4 weeks values was statistically significant $(P<0.05)$ (Table 2).
Table 2. \% reduction from baseline values of PASI score at the end of 4,8 and 12 week following treatments (Mean S+D)

\begin{tabular}{cccc}
\hline Weeks & $\begin{array}{c}\text { Group 1 } \\
\text { Ointment of } \\
\text { Nigella sativa }(\mathrm{n}=20)\end{array}$ & $\begin{array}{c}\text { Group 2 } \\
\text { Capsules of } \\
\text { Nigella sativa }(\mathrm{n}=20)\end{array}$ & $\begin{array}{c}\text { Group 3 } \\
\text { Combination of ointment and } \\
\text { capsules of Nigella sativa }(\mathrm{n}=20)\end{array}$ \\
\hline 4 & $21.7 \pm 11.2 \%$ & $19.6 \pm 7.8 \%$ & $29 \pm 8.7 \%$ \\
8 & $39 \pm 12 \%{ }^{*}$ & $34.2 \pm 11.4 \%^{*}$ & $54.7 \pm 7.2 \%{ }^{*}$ \\
12 & $52.6 \pm 7.1 \%{ }^{*}$ & $47.5 \pm 11.6 \%{ }^{*}$ & $62.1 \pm 13.6 \%{ }^{*}$ \\
\hline
\end{tabular}

* Significantly different from the corresponding 4 weeks value $(P$-value $<0.05)$.

\section{The clinical response to treatment}

At the end of 12 weeks treatment, complete cure of psoriatic lesions, excellent response and good response were noted in $85 \%$ of patients on the combination, while it was $65 \%, 50 \%$ in patients on the ointment and crude powder capsule respectively. Partial response was observed in 25\%,30\% and $10 \%$ of patients on ointment, crude powder capsule and the combination respectively. (Table 3 ).

\section{The onset of response to treatments}

The onset of response was marked after 4 weeks of treatment with the ointment of (NS), while the same response was achieved after 8 weeks with capsules of (NS)). The onset of response was faster in patients on the combination, in which improvement became clinically evident 2 weeks after treatment.

The disease relapsed in $31 \%, 50 \%$, and $18 \%$ of patients on the ointment, capsules, and the combination respectively. (Table 3 )
Table 3. Extent of response to various treatments at the end of 12 weeks of treatment and relapse after cessation of treatment.

\begin{tabular}{lccc}
\hline Response / Relapse & $\begin{array}{l}\text { Group 1 } \\
\text { Ointment n (\%) }\end{array}$ & $\begin{array}{l}\text { Group 2 } \\
\text { Capsules n (\%) }\end{array}$ & $\begin{array}{l}\text { Group 3 } \\
\text { Combination of ointment } \\
\text { and capsules n (\%) }\end{array}$ \\
\hline Complete cure & $1(5)$ & 0 & $2(10)$ \\
Excellent response & $2(10)$ & $1(5)$ & $4(20)$ \\
Good response & $10(50)$ & $9(45)$ & $11(55)$ \\
Partial response & $5(25)$ & $6(30)$ & $2(10)$ \\
No response & $2(10)$ & $4(20)$ & $1(5)$ \\
Relapse rate & $4(31)$ & $5(50)$ & $3(18)$ \\
\hline
\end{tabular}




\section{Patient's satisfaction}

High satisfaction was reported by $60 \%, 40 \%$ and $75 \%$ of patients treated with the ointment, capsule, and the combination respectively (Table 4 ). There was an association between the level of satisfaction and the use of the combination treatment but such association did not achieve statistical significance (Chi-square $=7.66, \mathrm{df}=4$, P-value 0.1 ).

Table 4. Patients satisfaction

\begin{tabular}{lccc}
\hline Satisfaction Groups & Highly satisfied & Partially satisfied & Not satisfied \\
\hline Ointment (Group 1) & $12(60 \%)$ & $6(30 \%)$ & $2(10 \%)$ \\
$\begin{array}{l}\text { Capsules (Group 2) } \\
\begin{array}{l}\text { Combination of ointment and } \\
\text { capsules (Group 3) }\end{array}\end{array}$ & $8(40 \%)$ & $5(25 \%)$ & $7(35 \%)$ \\
\hline
\end{tabular}

No association between the level of satisfaction and treatment dosage form (Chisquare $=7.66, \mathrm{df}=4, \mathrm{P}$-value 0.1 .

\section{Side effects}

(NS) was well tolerated with no reported side effects

\section{Parameter of oxidative stress (MDA)}

The mean baseline serum level of MDA was $1.04+0.23 \mu \mathrm{mol} / \mathrm{L}$ in patients on the ointment of (NS) $(10 \% \mathrm{w} / \mathrm{w})$ twice daily. The level was significantly decreased to $0.78+0.22 \mu \mathrm{mol} / \mathrm{L}$ at 12 weeks of treatment $(P<0.05)$.
In patients who received the capsule of crude powder of (NS) $500 \mathrm{mg}$, the mean baseline serum level of MDA was $1.09+0.37 \mu \mathrm{mol} / \mathrm{L}$ which was slightly and insignificantly reduced to $1.03+0.4$ $\mu$ mole/L at 12 weeks of treatment.

Patients who received the combination the mean baseline serum level of MDA was 1.2+0.37 $\mu \mathrm{mole} / \mathrm{L}$, which became $0.86+0.33 \mu \mathrm{mol} / \mathrm{L}$ at 12 weeks of treatment, the difference from baseline value was statistically significant $(P<0.05)$ (Table 5).

Table 5. Malondialdehyde) MDA) level before and after 12 weeks of treatment

\begin{tabular}{lcccc}
\hline & Baseline & 12 weeks & \% change & P value \\
\hline Ointment of Nigella sativa & $1.04 \pm 0.23$ & $0.78 \pm 0.22^{*}$ & $25 \%$ & $<0.05$ \\
Capsules of Nigella sativa & $1.09 \pm 0.37$ & $1.03 \pm 0.40$ & $5.5 \%$ & NS \\
$\begin{array}{l}\text { Combination of ointment and } \\
\text { capsules Nigella sativa }\end{array}$ & $1.2 \pm 0.37$ & $0.86 \pm 0.33^{*}$ & $43 \%$ & $<0.05$ \\
\hline
\end{tabular}

* Significantly different $(P$-value $<0.05)$ from the corresponding baseline value.

\section{Photographic viewing of patient response}

Photographs of psoriatic lesions were taken for all patients before starting treatment and at various stages throughout the study period. A representative patient was presented in figure 1 , in which clear improvement in psoriatic lesions is seen.
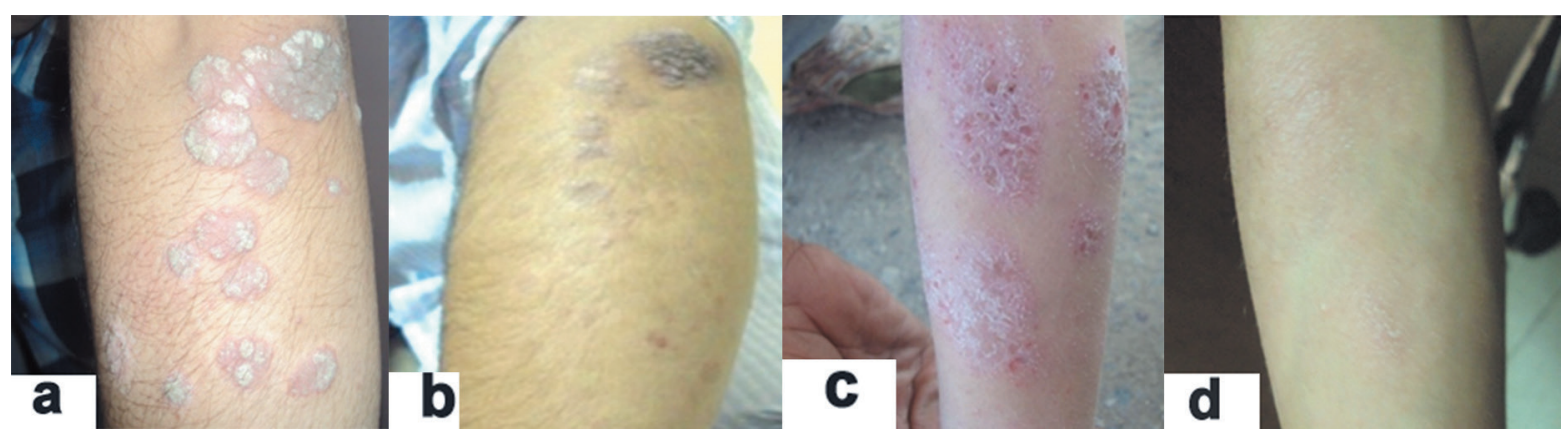

Figure 1. Photographic viewing of representative patients with psoriatic lesions of the left arm treated for 12 weeks with the combination (ointment and crude powder capsule of Nigella sativa). (a) before treatment (b), after treatment. Photographs (c) and (d) are for a representative patient with psoriatic lesion of the leg treated with ointment of Nigella sativa for 12 weeks (c) before treatment, (d) after treatment 


\section{DISCUSSION}

The present study provides an attempt to investigate the effectiveness of a herbal medication, (NS), which has been shown in some studies as an effective agent in the treatment of various dermatological diseases such as eczema, atopic dermatitis, acne and skin wrinkles $[7,8]$.

In the present work, the ointment of (NS) oil $(10 \% \mathrm{w} / \mathrm{w})$ achieved complete cure of psoriatic lesions and marked remission in (65\%) of cases after 12 weeks of treatment. The patients noticed improvement four weeks after starting the treatment. There was a great satisfaction among patients who were treated with the ointment preparation of (NS) since the patients found aromatic smell of (NS) pleasant, in addition, it did not stain and spoil clothes as other ointment preparations did. Compared with other routes of administration, the oil of (NS) as ointment contains more purified and concentrated constituents that probably, when used topically, delivers more active ingredients directly into the lesion at the site of application. The crude powder of (NS) in the form of capsules (500mg three times daily) achieved improvement in psoriatic lesion in fifty percent $(50 \%)$ of cases started to appear after 8 weeks of treatment, and showed satisfactory response at the end of 12 weeks. The onset of action was slower than treatment with either the ointment or the combination. Capsules of (NS) were not preferred by patients since most of them believed that skin diseases, like psoriasis, are better treated by topical preparations rather than oral medications. This, in part, explains poor compliance with a subsequent low cure rate among patients on oral treatment. Complete cure of psoriatic lesions achieved in $85 \%$ of patients treated with the combination seems additive. The onset of action appeared earlier with the combination treatment. A comparable effect on psoriatic lesion was obtained by principle drugs such as methotrexate or zinc [6].

Another important aspect of the effectiveness of (NS) in treating psoriatic lesion is its activity in palmoplanter psoriasis which is frequently described reluctant to treat as topical preparations have difficulty in penetrating the thick epidermis of palms and soles. In the present study there were 22 patients who had severe involvement of hands and feet with no involvement of other parts of the body, ten of them had been shown as highly responders to the combination of (NS) ointment and capsules. This indicates that the ointment of (NS) has the ability to penetrate the thick epidermis of palms and soles, thus exerting a direct effect on psoriatic lesions.

The study period was extended for 12 weeks and was completed during the summer season to eliminate possible seasonal variations related effects. One limitation to the study, a control group of psoriatic patients maintained on placebo treatment for that length of time was not studied for ethical reasons, therefore evaluation of the effectiveness of active treatments in respect to placebo effect was not possible.

In $(31 \%)$ of patients, the disease relapsed four weeks after cessation of treatment in patients on the ointment. Higher relapse rate $(50 \%)$ was observed in patients on the capsules. The combination of ointment and capsules is associated with the least relapse rate $(18 \%)$. In that respect, the combination has the advantage on other treatments in achieving better effect and having high remission rate, early onset of action and the least relapse rate.

In general, the response to treatment is determined by the dose of the administered drug or substance. The range of oral doses of (NS) in dermatological or other disease was not fully described. The selection of (NS) dose for the present study was based on information from various reports in man and also by extrapolation from experimental animals. The dose of (NS) for oral administration was $500 \mathrm{mg}$ three times daily and $10 \%$ ointment for topical use. Although it is frequently reported that (NS) is safe [20], there are some limitations to increase the doses since elevation in serum liver enzyme was reported after oral treatment with (NS) to mice [21]. In addition, a case report of contact dermatitis and recently a case of bullous eruption following topical application of (NS) oil were reported [22,23].

Malondialdehyde (MDA), formed from the breakdown of polyunsaturated fatty acid, serves as a convenient index of peroxidation reaction and oxidative stress. MDA was declined in psoriatic patients after 12 weeks of treatment in the three groups compared to pretreatment levels, the differences from the base line were statistically significant in two groups of patients (ointment and the combination groups), $p<0.05$.

The mechanism(s) by which (NS) produces anti- psoriatic effects is not well documented, however the following mechanisms can be considered, immunomodulation, $[10,11]$ antiangiogenesis [24,25], antiproliferative [26], antioxidant [12], antiinflammatory $[27,28]$, antibacterial [9], and antihistamine effects [13]. (NS) contains zinc which has 
been shown effective in treatment of psoriasis particularly those who are zinc deficient or those with low zinc levels [6]. In addition (NS) contains linoleic acid which was found low in psoriatic patients. Linoleic acid (unsaturated fatty acid) is an important constituent of (NS) that inhibits the production of leukotreine B4 and prostaglandin E2 which are involved in the pathogenesis of psoriasis [29]. It was found that there is an association between obesity and psoriasis,[30] in addition, psoriasis was reported to be associated with hyperlipidemia [31]. Therapeutic trial with statin found reduced serum lipid and remarkable reduction in PASI - score in psoriasis [32]. Thus in patients with psoriasis whether obese or not, (NS) through its lipid lowering effect [33], may benefit this group of patients.

In conclusion Nigella sativa (Black Cumin) is found effective in treatment of plaque and palmoplanter psoriasis. This effect is in agreement with the results of a study in which psoriatic lesions is induced in rats and treated with Nigella sativa [34]. Nigella sativa was well tolerated; no side effects were detected in the range of doses used in the present study.

\section{REFERENCES}

1. Griffiths CE, Barker JN. Pathogenesis and clinical features of psoriasis. Lancet 2007; 370:263-271.

2. Hunter JAA, Saven JA and Dahi MV. Psoriasis in Clinical dermatology-3rd Ed; Blackwell science Ltd 2002;5:40-51.

3. Mommers JM, van Erp PEJ, van de Kerkhof PCM. Clobetasol under Hydrocolloid Occlusion in Psoriasis Results in a Complete Block of Proliferation and in a Rebound of Lesions following Discontinuation. Dermatology 1999;199:323-327.

4. British Association of Dermatologists. Guidelines for management of patients with psoriasis. Workshop of the Re $\urcorner$ search Unit of the Royal College of Physicians of London; Department of Dermatology, University of Glasgow. BMJ 1991;303:829-835.

5. Reich K, Nestle FO, Papp K, et al. Infliximab induction and maintenance therapy for moderate to severe psoriasis: A phase III, multicentre, double -blind trial. Lancet 2005;366:1367-1374.

6. Ahmed JH, Abd SR, Al-Hamdi KI. Effectiveness of oral zinc sulfate, oral methotrexate and their combination in the treatment of psoriasis. J ClinExp Invest 2010;1:134-149.

7. Kalus U, Pruss A, Bystron J, et al. Effect of Nigella sativa (black seed) on subjective feeling in patients with allergic diseases. Phytother Res 2003;17:1209-1214.

8. Sharquie KE, Al-Nuaimy AA, JaburSS. Topical 10\% Black Seed (Nigella sativa) Ointment: A new rem- edy for atopic dermatitis. JSSDDS 2006; available in: http://www.jssdds.org/index.php?option=com_medi\&t ask=viewfulltext\&rowid=31\&ltemid=99999999

9. Hanafy MS, Hatem ME. Studies on the antimicrobial activity of Nigella sativa seed (black cumin). J Ethnopharmacol 1991;34:275-278.

10. Haq A, Lobo PI, Al-Tufail M, et al. Immunomodulatory effect of Nigella sativa proteins fractionated by ion exchanged chromatography. Int J Immunopharmacol 1992;21:283-295.

11. Haq A, Abdulatif M, Lobo PI, et al. Nigella sativa: effect on human lymphocytes and polymorphonuclear leukocyte phagocytic activity. Immunopharmacology 1995;30:147-155.

12. Kanter M, Coskun $\mathrm{O}$, Uysal $\mathrm{H}$. The antioxidative and antihistaminic effect of Nigella sativa and its major constituent, thymoquinone on ethanol-induced gastric mucosal damage. Arch Toxicol 2006;80:217-224.

13. Chakravatry $\mathrm{N}$. inhibition of histamine release from mast cells by nigellone. Ann Allergy 1993;70:237-242.

14. Shoieb AM, Elgayyar M, Dudrick PS, et al. In vitro inhibition of growth and induction of apoptosis in cancer cell lines by thymoquinone. Int J Oncol 2003;22:107113.

15. Gurung RL, Lim SN, Khaw AK, et al. Thymoquinone Induces Telomere Shortening, DNA Damage and Apoptosis in Human Glioblastoma Cells. PLoSONE 2010;5:e12124.

16. Röhrig B, du Prel J, Wachtlin D, et al. Sample size calculation in clinical trials. Dtsch Arztebl Int 2010;107:552-556.

17. Dave's M. The Psoriasis Area and severity Index: Internet 2003, available in http://www.Dave'sPsoriasisInfo. com.

18. Carlin CS, Feldman SR , Krueger JG, et al. A $50 \%$ reduction in the Psoriasis area and Severity Index (PASI) is a clinical significant end Point in the assessment of Psoriasis. J Am Acad Dermatol 2004;50:859866.

19. Bueg JA, Aust SD. Microsomal lipid peroxidation. Method Enzymol 1978;52:302-310.

20. Zaoui A, Cherrah Y, Mahassini N, et al. Acute and chronic toxicity of Nigella sativa fixed oil. Phytomedicine 2002;9:69-74.

21. Vahdati-Mashhadian N, Rakhshandeh $\mathrm{H}$, OmidiA. An investigation on LD50 and subacute hepatic toxicity of Nigella sativa seed extracts in mice. Pharmazie 2005;60:544-547.

22. Zedlitz S, Kaufmann R, Boehncke WH. Allergic contact dermatitis from black cumin (Nigella sativa) oilcontaining ointment. Contact Dermatitis 2002;46:188.

23. Gelot P, Bara-Passot C, Gimenez-Arnau E, et al. Bullous drug eruption with Nigella sativa oil. Ann DermatolVenereol. 2012;139:287-291.

24. Yi T, Cho SG, Yi Z, et al. Thymoquinone inhibits tumour angiogenesis and tumour growths through suppress- 
ing AKT and extracellular signal- regulated kinase signaling pathways. Mol Cancer Ther 2008;71:789-796.

25. Banerijee S, Padhye S, Azmi A, et al. Review on molecular and therapeutic potential of thymoquinone in cancer. NutrCancer 2010;62:938-946.

26. Li F, Rajendran P, Sethi G. Thymoquinone inhibits proliferation, induces apoptosis and chemosensitizes human multiple myeloma cells through suppression of signal transducerand activator of transcription 3activation pathway. Br J Pharmacol 2010;161:541-554.

27. Marsik P, KokoskaL, Landa P, et al. In vitro inhibitory effects of thymol and quinines of Nigella sativa seeds on cyclooxygenase-1- and -2- catalyzed prostaglandin E2 biosynthesis. PlantaMed 2005;71:739-742.

28. Tekeoglu I, Dogan A, Demiralp L. Effects of thymoquinone (volatile oil of black cumin) on rheumatoid arthritis in rate models. Phytother Res 2006;20:869-871.
29. Namazi MR. The beneficial and detrimental effects of linoleic acid on autoimmune disorders. Autoimmunity 2004;37:73-75.

30. HenselerT, Christophers E. Disease concomitance in psoriasis. J Am Acad Dermatol 1995;32:982-986.

31. Piskin S, Gurkok F, Ekuklu G, Senol M. Serum lipid levels in psoriasis. Yonsei Med J 2003;44:24-26.

32. Wakkee M, Thio HB, Prens EP, et al. Unfavorable cardiovascular risk profiles in un treated and treated psoriasis patients. Atherosclerosis 2007;190:1-9.

33. Dahri AH, Chandiol AM, Rahoo AA, Memon RA. Effect of Nigella sativa (Kalonji) on serum cholesterol of albino rats. J Ayub Med Coll Abbottabad. 2005;17:72-74.

34. Dwarampudi LP, Palaniswamy D, Nithyanantham M, Raghu PS. Antipsoriatic activity and cytotoxicity of ethanolic extract of Nigella sativa seeds. Pharmacogn Mag. 2012;8:268-272. 